\title{
Intrapartum fever and antibiotic therapy - a quality assurance study
}

\section{Kristin Bøhn}

Fagutviklingsjordmor

Fødeavdelingen, Oslo universitetssykehus, Ullevål

\section{Siv Merethe Amundsen}

Jordmor

Fødeavdelingen, Oslo universitetssykehus, Ullevål

\section{Katariina Laine}

Avdelingsleder, overlege og førsteamanuensis

Kvinneklinikken, Oslo universitetssykehus og Avdeling for helseledelse og helseøkonomi, Universitetet i Oslo

\section{Dorte Hvidtjørn}

Jordmor og førsteamanuensis II

Universitetet i Sørøst-Norge og Aarhus Universitetshospital, Danmark

\section{Aase Devold Pay}

Assisterende avdelingsleder og førsteamanuensis

Fødeavdelingen, Oslo universitetssykehus og Fakultet for helsevitenskap, Oslomet storbyuniversitetet

\section{\begin{tabular}{lllll} 
Quality Antibiotics Labour Fever Cross-sectional study \\
\hline
\end{tabular}}

\section{Summary}

Background: Intrapartum fever is defined as body temperature $\geq 38^{\circ} \mathrm{C}$ and occurs in about 7 per cent of full-term births. The condition may increase the risk of maternal and neonatal morbidity and mortality. Correct use of antibiotics can reduce the incidence of serious outcomes for mother and child. 
Objective: Survey the incidence of intrapartum fever and the use of antibiotics for this indication at the Maternity Department of Oslo University Hospital Ullevål, and determine whether the use of antibiotics was in accordance with the division's procedures.

Method: Review of the records of patients with full-term births who were admitted to the Maternity Department in the period 1-30 April 2018.

Results: Intrapartum fever was recorded in 67 of $55^{2}$ patients (12 per cent). Ninety-nine patients (18 per cent) received therapy with antipyretics and/or antibiotics because of fever. Of these, 53 received penicillin ( 54 per cent) on the grounds of suspected infection. The criteria according to the current procedures for prophylactic antibiotic therapy were fulfilled for 38 of the 53 patients who received penicillin (72 per cent). Penicillin in combination with gentamycin was administered to 21 of 99 patients ( 21 per cent) on an indication of clinical chorioamnionitis (inflammation of the fetal membranes). Of these 21 patients, 15 (71 per cent) fulfilled the criteria for treatment.

Conclusion: We found a higher incidence of intrapartum fever than described in the literature. A review of patient records showed that the use of antibiotics was in accordance with procedures in several areas, but that there were problems with overtreatment.

Intrapartum fever, defined as a body temperature of $\geq 38^{\circ} \mathrm{C}$ during labour, is a clinical diagnosis that requires close monitoring and treatment in order to prevent serious complications to the health of mother and child (1-5).

Recent cohort studies show an incidence of around seven per cent in full-term births ( $\geq 37$ th week of pregnancy) $(2,5)$. Intrapartum fever may have an infectious or non-infectious aetiology, and the consequences for mother and child will depend on the cause (2).

Greater risk for mother and child is associated with fever in non-infectious circumstances, which include surgical vaginal delivery and caesarean section (2, 3, 6), an Apgar score of $<7$ at the age of 5 minutes, a need for resuscitation and convulsions. The risk to the child of brain damage is four times as high $(7,8)$. Fever due to infection heightens the risk of complications $(2,9)$. 


\section{Risk factors for intrapartum fever}

The risk factors for intrapartum fever include being nulliparous, having protracted labour, premature release of amniotic fluid and repeated vaginal examinations $(3,5$, 10, 11).

Pregnant women with these risk factors also have a higher risk of developing intraamniotic infection (IAI), i.e. inflammation of membranes, placenta and amniotic fluid due to bacterial infection, and/or of being given epidural anaesthesia, which are the two most common causes of intrapartum fever $(1,2)$. In the absence of an existing febrile disorder, such as a respiratory tract infection, most pregnant women who develop intrapartum fever are treated with broad-spectrum antibiotics because of assumed IAI.

In the guidance on birthing assistance (12) and local procedures, antibiotic therapy and prompt planning of delivery are recommended on suspicion of IAI. If fever occurs with no sign of infection, general fever-reducing measures with paracetamol and fluid by mouth or intravenously are proposed.

If the fever persists and there are no other clinical signs of infection, it is recommended that penicillin be used prophylactically, but in the event of fever with two of five supplementary criteria (see Table 1 for supplementary criteria), the use of a broad-spectrum antibiotic is recommended.

Fever is the most important clinical sign of IAI, and no concrete laboratory findings or clinical signs distinguish reliably between IAI and epidural-related fever $(2,11$, 13). The aetiology behind epidural-related fever is unclear, but underlying noninfectious inflammatory processes have been identified (7).

The low threshold for diagnosis and antibiotic treatment of IAI may therefore lead to overtreatment, as the fever of many of these patients is subsequently found not to have an infectious cause $(3,5,6,9)$.

\section{The objective of the study}

The aim of the study was to identify the extent of intrapartum fever and survey the use of antibiotics administered on this indication in a given period at the Maternity Department of Oslo University Hospital Ullevål (OUH).

In addition, the study has a quality assurance perspective, as we investigated the extent to which the antibiotic therapy procedures were complied with in the maternity department. Adherence to procedures is an important part of quality assuring the medical assistance offered. 
Table 1. Local procedures for intrapartum fever and chorioamnionitis

\begin{tabular}{|c|c|c|}
\hline & Criteria & Intervention \\
\hline 1) Intrapartum fever & Temperature $\geq 38^{\circ} \mathrm{C}$ & $\begin{array}{l}\text { General treatment: } \\
\text { Paracetamol } 1 \mathrm{~g} \text {, } \\
1000 \mathrm{ml} \text { Ringer Acetate, } \\
\text { lower room temperature }\end{array}$ \\
\hline 2) Suspicion of infection & $\begin{array}{l}\text { Lack of response to } 1 \text { ) after 20-30 } \\
\text { minutes }\end{array}$ & $\begin{array}{l}\text { Penicillin G } 1.2 \mathrm{~g} \times 4 \text { i.v., } \\
\text { start at least } 1 \text { hour before labour }\end{array}$ \\
\hline \multirow[t]{5}{*}{ 3) Clinical chorioamnionitis } & $\begin{array}{l}\text { Lack of response to } 1 \text { ) and at least } \\
\text { two of the following supplementary } \\
\text { criteria: }\end{array}$ & $\begin{array}{l}\text { Penicillin G } 1.2 \mathrm{~g} \times 6 \text { i.v. and gentamy- } \\
\text { cin } 5 \mathrm{mg} / \mathrm{kg} \times 1 \text { i.v. }\end{array}$ \\
\hline & - maternal tachycardia & \\
\hline & $\geq 100$ beats per minute & \\
\hline & - fetal tachycardia & \\
\hline & $\geq 160$ beats per minute & \\
\hline
\end{tabular}

\section{Method}

\section{Design and selection}

The study was a descriptive cross-sectional study with a retrospective review of the patient records on all births in the period 1-30 April 2018 at Ullevål Maternity Department, OUH. Ullevål Maternity Department consists of two maternity units and one low-risk unit.

Patients with full-term pregnancies in active labour, i.e. with regular contractions and vaginal dilation of $\geq 3 \mathrm{~cm}$ (14), were used to estimate the incidence of intrapartum fever and antibiotic therapy on this indication.

Detailed information was obtained from Partus, the electronic birth records system, DIPS, the electronic patient records system, and STAN Viewer (Neoventa), the fetal monitoring system, which contained information on maternal, obstetric and neonatal characteristics, outcomes and treatment methods.

We quality-assured the data by means of a manual review of all records without taking account of procedure codes or medical diagnoses related to fever, infection and antibiotic therapy during active labour.

The material was structured and analysed descriptively. We present the results in the form of median and range for continuous data and frequency and percentage for category data. The study was approved by the Data Protection Officer at OUH on 5 February 2019 (case no. 19/03137). 
We registered and analysed the data in anonymised form. There was no subject identity list or registration of personal identity numbers or names. As a quality assurance study, it was not required to be submitted to the Regional Committees for Medical and Health Research Ethics (REK).

\section{Results}

In 2018 there were 6861 births at Ullevål Hospital, which was 12.5 per cent of all births in Norway (55 072) (15). Of the total of 621 births in the study period, 69 were excluded (Figure 1).

At the start of active labour, the remaining 552 had passed week $37+0$. The review of medical records showed that 99 of 552 patients (18 per cent) received general antipyretic treatment and/or antibiotics on the grounds of suspected infection during labour or IAI. A documented temperature of $\geq 38^{\circ} \mathrm{C}$ was found in 67 of 552 patients (12 per cent).

Maternal, obstetric and neonatal characteristics of patients who received medical therapy in connection with elevated body temperature $(n=99)$ are presented in Table 2.

Figure 1. Selection process

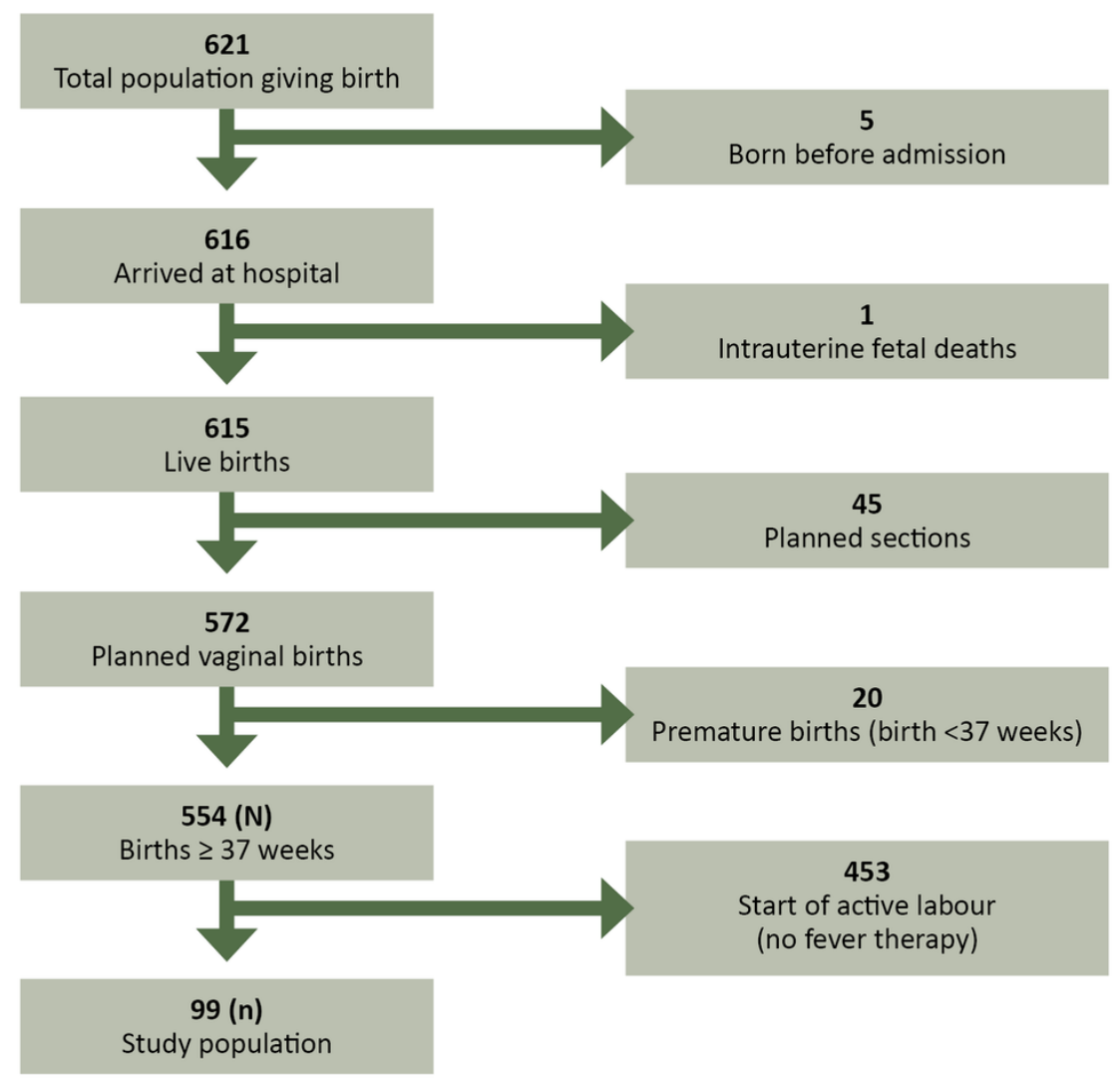


Table 2. Maternal, obstetric and neonatal characteristics of patients who received medical therapy in connection with elevated body temperature in the study period ( $n=99)$.

\begin{tabular}{|c|c|}
\hline Maternal factors & Treated for fever $(\mathrm{n}=99)$ Median [range], No. $(\%)$ \\
\hline Age & $32[22-43]$ \\
\hline Nulliparous & $86(87)$ \\
\hline Duration of pregnancy in days & $283[261-294]$ \\
\hline \multicolumn{2}{|l|}{ Obstetric factors } \\
\hline Start of labour, spontaneous/induced & $52(53) / 47(47)$ \\
\hline Duration of labour stage 1 & $7[1-17]$ \\
\hline Duration of labour stages $1+2$ & 9 [1-19] \\
\hline Amniotic fluid release, no. of hours & $13[0-88]$ \\
\hline Discoloured amniotic fluid & $26(26)$ \\
\hline Epidural anaesthesia & $89(90)$ \\
\hline Epidural anaesthesia, no. of hours & $9[2-30]$ \\
\hline Epidural anaesthesia, duration, number $<7$ hours $/ \geq 7$ hours & $20(22) / 69(78)$ \\
\hline No. of vaginal examinations after admission & $11[3-22]$ \\
\hline Number of vaginal examinations before temperature intervention & $6[0-16]$ \\
\hline Oxytocin stimulation & $86(87)$ \\
\hline Spontaneous vaginal birth & $52(53)$ \\
\hline Surgical vaginal birth & $32(32)$ \\
\hline Emergency caesarean section & $15(15)$ \\
\hline Haemorrhaging $>1000 \mathrm{ml}$ & $19(19)$ \\
\hline Antibiotic therapy postpartum & $2(2)$ \\
\hline \multicolumn{2}{|l|}{ Neonatal factors } \\
\hline Apgar $<7$ after 5 minutes & $2(2)$ \\
\hline Transferred to neonatal ICU & $3(3)$ \\
\hline Antibiotic therapy in neonatal ICU & $2(2)$ \\
\hline
\end{tabular}

\section{Intrapartum fever and general treatment}

General treatment for fever (antipyretic therapy: paracetamol combined with intravenous fluid) was administered to 92 of 99 patients (93 per cent) (Table 3). It was documented that of the remaining seven women, five received intravenous fluid with fever as an indication without paracetamol being documented.

In two cases, penicillin was administered because of fever, though antipyretic therapy was not documented. At the commencement of general treatment, 44 patients had temperatures of under $38.0^{\circ} \mathrm{C}$, while 48 had temperatures of between $38.0^{\circ} \mathrm{C}$ and $38.7^{\circ} \mathrm{C}$.

\section{Suspected infection and prophylactic antibiotic therapy}

Penicillin was administered to 53 of 99 patients (54 per cent) on suspicion of infection (Table 4), and 38 of the 53 ( 72 per cent) fulfilled the criteria. Of the 15 patients who did not fulfil the criteria, five were started on penicillin before the effect of general treatment was assessed. 
Eight patients had temperatures of $<38^{\circ} \mathrm{C}$, while the temperatures of two were not recorded. The highest temperature measured for these patients during labour was $38.1^{\circ} \mathrm{C}$. Three patients met the requirements for but did not receive penicillin therapy.

\section{Clinical chorioamnionitis and treatment with penicillin and gentamycin}

Twenty-one of 53 patients (40 per cent) received penicillin in combination with gentamycin (Table 4). Fifteen of these 21 (71 per cent) received treatment in accordance with the guidelines.

Of the six patients who did not meet the criteria, two had temperatures under $38^{\circ} \mathrm{C}$. The three others had temperatures of $38.0-38.1^{\circ} \mathrm{C}$ and zero or one supplementary factor. The temperature of one of them was not recorded. All patients who were supposed to receive treatment, did receive it.

Table 3. Patients who received antipyretic therapy in the study period

\begin{tabular}{|c|c|c|}
\hline \multicolumn{3}{|l|}{ Antipyretic therapy $(n=99)$} \\
\hline $92 / 99(93 \%)$ & $5 / 99(5 \%)$ & $2 / 99(2 \%)$ \\
\hline $\begin{array}{l}\text { General treatment: paracetamol } 1 \mathrm{~g}+\text { intravenous } \\
\text { fluid, Ringer Acetate (RA) }\end{array}$ & RA & Unknownt \\
\hline $48 / 92(52 \%)$ & $44 / 92(48 \%)$ & \\
\hline Fulfilled criteria for treatment & Did not fulfil criteria for general treatment & \\
\hline Temperature at start $\left[38,0-38,7^{\circ} \mathrm{C}\right]$ & Temperature at start $\left[37,1-37,9^{\circ} \mathrm{C}\right]$ & \\
\hline
\end{tabular}


Table 4. Antibiotic therapy for patients who received antipyretic treatment $(n=99)$

\begin{tabular}{|c|c|c|c|c|c|}
\hline \multicolumn{6}{|c|}{ Antibiotic therapy for patients who received antipyretic treatment $(n=99)$} \\
\hline \multicolumn{4}{|l|}{$53 / 99(54 \%)$} & \multirow{2}{*}{\multicolumn{2}{|c|}{$\begin{array}{l}\text { 46/99 (46\%) } \\
\text { No antibiotics }\end{array}$}} \\
\hline \multicolumn{4}{|c|}{ Penicillin (PC) 1,2 g x 4} & & \\
\hline \multicolumn{2}{|l|}{$38 / 53(72 \%)$} & \multicolumn{2}{|c|}{$15 / 53(28 \%)$} & $43 / 46(93 \%)$ & $3 / 46(7 \%)$ \\
\hline \multicolumn{2}{|c|}{ Fulfilled criteria for treatment } & \multicolumn{2}{|c|}{ Did not fulfil criteria for treatment } & Correct treatment & Fulfilled \\
\hline \multicolumn{2}{|c|}{$\begin{array}{l}\text { Correct treatment } \\
{\left[38,0-38,9^{\circ} \mathrm{C}\right]}\end{array}$} & \multicolumn{2}{|c|}{$\begin{array}{l}\text { Temperature at start } \\
{\left[37,2-38,1^{\circ} \mathrm{C}\right]}\end{array}$} & $\begin{array}{l}\text { Effect of general } \\
\text { treatment or/and } \\
\text { temperature }<38{ }^{\circ} \mathrm{C}\end{array}$ & $\begin{array}{l}\text { Did not } \\
\text { receive PC }\end{array}$ \\
\hline \multicolumn{3}{|l|}{$21 / 53(40 \%)$} & $32 / 53(60 \%)$ & & \\
\hline \multicolumn{3}{|c|}{ Penicillin + gentamycin $5 \mathrm{mg} / \mathrm{kg}$} & $\begin{array}{l}\text { Not treated for } \\
\text { clinical chorioam- } \\
\text { nionitis }\end{array}$ & & \\
\hline $15 / 21(71 \%)$ & $5 / 21(24 \%)$ & $1 / 21(5 \%)$ & $32(100 \%)$ & & \\
\hline $\begin{array}{l}\text { Fulfilled criteria } \\
\text { for treatment }\end{array}$ & $\begin{array}{l}\text { Did not fulfil } \\
\text { criteria }\end{array}$ & & & & \\
\hline $\begin{array}{l}\text { Tempera- } \\
\text { ture at start } \\
{\left[38,0-38,6^{\circ} \mathrm{C}\right]}\end{array}$ & $\begin{array}{l}\text { Temperature at } \\
\text { start } \\
{\left[37,6-38,1^{\circ} \mathrm{C}\right]}\end{array}$ & Unknown & Correct treatment & & \\
\hline
\end{tabular}

\section{Discussion}

The results show that intrapartum fever complicated almost one of eight full-term deliveries, as 67 of $55^{2}$ patients ( 12 per cent) had a temperature of $\geq 38^{\circ} \mathrm{C}$ during active labour. A total of 99 of 552 (18 per cent) received some form of medical therapy as a result of elevated temperature. Procedures were largely adhered to, but there were problems with overtreatment.

\section{«The results show that intrapartum fever complicated almost one of eight full-term deliveries.»}

International studies show an overall incidence of intrapartum fever of around seven per cent $(1,2,5)$. This figure is somewhat lower than we found in our study. Study designs, study populations, incidence of risk factors and obstetric practice vary across studies, so the incidence is not necessarily comparable.

The majority of the patients in our study who received therapy for fever were nulliparous (87 per cent) and received epidural anaesthesia (90 per cent). Studies show that parity and use of epidurals are associated with intrapartum fever $(6,8$, 11). 
It is possible that the high incidence of fever in our population can be partly explained by extensive use of epidural anaesthesia and a high proportion of nulliparous women. Epidural-related fever is reported with an incidence of between 13 and 33 per cent in nulliparous women and is viewed in the context of protracted labour, multiple interventions and more extensive use of epidural anaesthesia $(8,11,16)$.

\section{«It is possible that the high incidence of fever in our population can be partly explained by extensive use of epidural anaesthesia and a high proportion of nulliparous} women.»

In addition, our population represented a number of known risk factors: about half (47 per cent) were induced, a third of them on the indication of protracted amniotic fluid discharge. Almost two-thirds received oxytocin to stimulate contractions because of protracted labour and numerous vaginal examinations.

Several studies show that repeated vaginal examinations are an independent risk factor for intrapartum fever and IAI, and found that the number of vaginal examinations correlates with the percentage increase in IAI $(17,18)$.

A significant proportion of the patients had a ventouse or forceps delivery or an emergency caesarean section. (15 per cent). The results are consistent with those of studies showing that intrapartum fever causes increased risk of obstetric interventions $(3,9)$.

Fever and intrauterine inflammation may be the cause of dysfunctional contractions, protracted labour and severe post-partum haemorrhage, and they also increase the risk of neonatal hypoxia. Neonatal outcomes were good, with few children with Apgar $<7$ at the age of 5 minutes (2/99) and/or in need of antibiotic therapy (2/99).

None of the children who were transferred to the neonatal ICU were in the group with clinical chorioamnionitis. The mothers of two of the children had received penicillin, and one mother qualified for penicillin but did not get it. The low proportion of neonatal sepsis in the fever group is consistent the finding of several studies that assumed IAI subsequently shows absence of infectious cause $(2,5,9$, 19). 


\section{General treatment and use of antibiotics}

General treatment with paracetamol and intravenous fluid was administered to 92 of 99 (93 per cent), despite the fact that only approximately half (48 of 92, 52 per cent) fulfilled the requirements according to the division's procedures. The aim of preventing intrapartum fever in connection with rising body temperature during labour may possibly explain why these patients received this treatment.

Although paracetamol and intravenous fluid are regarded as having few adverse effects, there is little evidence in the literature that paracetamol has a preventive or antipyretic effect on the temperature of an intrapartum patient $(20,21)$.

\section{«The majority received the correct treatment on suspicion of infection.»}

The study results indicate that the division's midwives and doctors place great emphasis on identifying intrapartum fever and relevant predictors during labour, and in consequence the majority received the correct treatment on suspicion of infection.

However, for some patients (28 per cent), antibiotics treatment was initiated sometimes unnecessarily or at an earlier stage than indicated by the procedures. It is reasonable to assume that the extensive use of antibiotics is attributable to a fear of overlooking an intrauterine infection, rather than lack of knowledge of the procedures.

Our findings are consistent with several studies that have investigated adherence by health professionals to evidence-based guidelines for antibiotic therapy. These studies concluded that breaches of the procedures for prescribing antibiotics tend largely to take the form of overtreatment. The reason was partly lack of trust in evidence-based guidelines and partly a precautionary principle $(22,23)$.

An important part of the quality assurance work in intrapartum care is to monitor developments and evaluate practice (24). We find that recommendations from the guidance on birthing assistance and local procedures on intrapartum fever and chorioamnionitis are not optimally adhered to.

\section{«Right treatment for the right patient will be an important task going forward.»}


Increased effort to reduce and optimise the use of antibiotics - the right treatment for the right patient - will be important going forward to minimise adverse effects on mother and child and reduce the development of resistance (25). Unnecessary use of antibiotics will be reduced if recommended guidelines and procedures are followed.

\section{Strengths and weaknesses of the study}

The study provides an overview of current practice in the Maternity Department at Ullevål Hospital. In reviewing 621 sets of patient records, we have obtained information for each individual case from a large, population-based birth database. It is conceivable that some records contain incorrect or deficient documentation.

The study is a description of a sample, and there is therefore no control group. Consequently, the study cannot provide answers regarding correlations between maternal and neonatal characteristics, obstetric variables and risk of intrapartum fever.

The study is a cross-sectional study, and reflects clinical practice in a given time period. The period is relatively short, at a month, and the results must be interpreted accordingly. Experience shows that some phenomena vary from month to month, and although the number of data points is relatively large, the results may nevertheless represent a sample that cannot be generalised to other populations.

\section{Conclusion}

We found a higher incidence of intrapartum fever than described in the literature. Our findings show that treatment for fever was largely in accordance with the guidance and local procedures, but that there were problems associated with overtreatment with antibiotics.

It is important for the department to be aware of the extent to which procedures are complied with, to enable them to develop measures to bring about improvement and subsequently evaluate the effect of the measures implemented.

\section{References}

1. Ashwal E, Salman L, Tzur Y, Aviram A, Ben-Mayor Bashi T, Yogev Y, et al. Intrapartum fever and the risk for perinatal complications - the effect of fever duration and positive cultures. J Maternal Fetal Neonatal Med. 2018;31(11):1418-25.

2. Chen K. Intrapartum fever. UpToDate. 2019. Available at:

https://www.uptodate.com/contents/intrapartum-fever (downloaded 20.10.2019). 
3. Greenwell EA, Wyshak G, Ringer SA, Johnson LC, Rivkin MJ, Lieberman E. Intrapartum temperature elevation, epidural use, and adverse outcome in term infants. Pediatrics. 2012;129(2):e447-54.

4. Shatrov JG, Birch SC, Lam LT, Quinlivan JA, McIntyre S, Mendz GL. Chorioamnionitis and cerebral palsy: a meta-analysis. Obstetrics and Gynecology. 2010;116(2 Pt 1):387-92.

5. Towers CV, Yates A, Zite N, Smith C, Chernicky L, Howard B. Incidence of fever in labor and risk of neonatal sepsis. Am J Obstet Gynecol. 2017;216(6):596.e15.

6. Apantaku O, Mulik V. Maternal intra-partum fever. Am J Obstet Gynecol. 2007;27(1):12-5.

7. Riley LE, Celi AC, Onderdonk AB, Roberts DJ, Johnson LC, Tsen LC, et al. Association of epidural-related fever and noninfectious inflammation in term labor. Obstet Gynecol. 2011;117(3):588-95.

8. Goetzl L. Epidural analgesia and maternal fever: a clinical and research update. Curr Opin Anaesthesiol. 2012;25(3):292-9.

9. Tita A. Intra-amniotic infection (clinical chorioamnionitis or triple I). UpToDate. 2019. Available at: https://www.uptodate.com/contents/intra-amnioticinfection-clinical-chorioamnionitis-or-triple-i (downloaded 09.09.2019).

10. Anim-Somuah M, Smyth RM, Cyna AM, Cuthbert A. Epidural versus nonepidural or no analgesia for pain management in labour. Am J Obstet Gynecol. Jun. 2017;216(6):596.e1-5. Available at:

https://www.cochranelibrary.com/cdsr/doi/10.1002/14651858.CDoo0331.pub4/inform ation (downloaded 20.02.2019).

11. Curtin WM, Katzman PJ, Florescue H, Metlay LA, Ural SH. Intrapartum fever, epidural analgesia and histologic chorioamnionitis. J Perinatol. 2015;35(6):396-400.

12. Norsk gynekologisk forening. Veileder i fødselshjelp. Feber under fødsel og chorioamnionitt. Oslo: Den norske legeforening; 2020. Available at: https://www.legeforeningen.no/foreningsledd/fagmed/norsk-gynekologiskforening/veiledere/veileder-i-fodselshjelp/ (downloaded 01.09.2020). 
13. Randis TM, Polin RA, Saade G. Chorioamnionitis: time for a new approach. Curr Opin Pediatr. Apr. 2017;29(2):159-64. Available at:

https://journals.lww.com/co-

pediatrics/Abstract/2017/04000/Chorioamnionitis__time_for_a_new_approach.7.a

spx (downloaded 15.10.2019).

14. Oslo universitetssykehus (OUS). Normal fødsel. Oslo: OUS; 2019. Available at: http://ehandbok.ous-hf.no/document/27405 (downloaded 02.03.2019).

15. Folkehelseinstituttet. Medisinsk fødselsregister for 2018. Oslo:

Folkehelseinstituttet: 2019. Available

at: http://statistikkbank.fhi.no/mfr/ (downloaded 15.09.2019).

16. Sultan P, David AL, Fernando R, Ackland GL. Inflammation and epiduralrelated maternal fever: proposed mechanisms. Anesth Analg. 2016;122(5):1546-53.

17. Kovo M, Schreiber L, Ben-Haroush A, Shor S, Golan A, Bar J. Intrapartum fever at term: clinical characteristics and placental pathology. J Matern Fetal Neonatal Med. 2012;25(8):1273-7.

18. Seaward PG, Hannah ME, Myhr TL, Faine D, Ohlsson A, Wang EE, et al. International multicentre term prelabor rupture of membranes study: evaluation of predictors of clinical chorioamnionitis and postpartum fever in patients with prelabor rupture of membranes at term. Am J Obstet Gynecol. Nov. 1997;177(5):1024-9.

19. Sharpe EE, Arendt KW. Epidural labor analgesia and maternal fever. Clin Obstet Gynecol. 2017;60(2):365-74.

20. Goetzl L, Rivers J, Evans T, Citron DR, Richardson DE, Lieberman E, et al. Prophylactic acetaminophen does not prevent epidural fever in nulliparous women: a double-blind placebo-controlled trial. J Perinatol. Mai 2004;24(8):471.

21. Lavesson T, Källén K, Olofsson P. Fetal and maternal temperatures during labor and delivery: a prospective descriptive study. J Matern Fetal Neonatal Med. 2018;31(12):1533-41.

22. Gouvêa M, Novaes CdeO, Pereira DMT, Iglesias AC. Adherence to guidelines for surgical antibiotic prophylaxis: a review. Braz J Infect Dis. 2015;19(5):517-24. 
23. European Centre for Disease Prevention and Control. Systematic review and evidence-based guidance on perioperative antibiotic prophylaxis. Stockholm: ECDC; 2013. Available at: https://www.ecdc.europa.eu/en/publicationsdata/systematic-review-and-evidence-based-guidance-perioperative-antibiotic (downloaded 10.10.2019).

24. Helsedirektoratet. Et trygt fødetilbud. Kvalitetskrav til fødselsomsorgen. Oslo: Helsedirektoratet; 2012. Available at: https://www.helsedirektoratet.no/veiledere/et-trygt-fodetilbud-kvalitetskrav-tilfodselsomsorgen2012 (downloaded 20.09.2019).

25. Antibiotikasenteret for primærmedisin (ASP), Nasjonal kompetansetjeneste for antibiotikabruk i spesialisthelsetjenesten (KAS). Hva er antibiotikaresistens? [Internet]. ASP, KAS; 14.10.2019 [cited 22.10.2019]. Available at: https://www.antibiotika.no/hva-er-antibiotikaresistens/ 